DOI: 10.19085/journal.sijmas031002

\title{
Mathematics and blindness: let's try to solve this problem?
}

\author{
Pinho, T.M.M. ${ }^{1}$, Castro, H.C. ${ }^{1,2}$; Alves, L. ${ }^{2}$, Lima N.R.W. ${ }^{1}$ \\ ${ }^{1} \mathrm{CMPDI}$, Instituto de Biologia, UFF, RJ, Brazil \\ ${ }^{2} \mathrm{PPBI}$, Instituto de Biologia, UFF, RJ, Brazil.
}

(c) Scholedge International Journal of Multidisciplinary \& Allied Studies (ISSN 2394-336X), Vol.03, Issue 10 (2016) pg215-225. Published by: Scholedge R\&D Center [http://www.thescholedge.org/journals/] [Email: editorial@thescholedge.org]

\begin{abstract}
According to World Health Organization, the number of people with blindness due to infectious diseases has reduced in the last 20 years whereas $80 \%$ of all visual impairment can be prevented or cured. Despite of that, 285 million people are estimated to be visually impaired worldwide as about $90 \%$ are from low-income society. Considering this scenario, it is still necessary to think about this public and know how to teach them disciplines such as Mathematics that are important to their lives as citizens. The Mathematics concepts are always in need for living in our society as we have to pay bills and considering that Mathematics knowledge is demanded all time from health to payment. In this article, we briefly discuss the blindness and the Mathematics universe, pointing this educational area as one that should be more educational developed. The article also intends to stimulate and contribute for the production of new strategies and didactical materials for teaching Mathematics to this public with special needs.
\end{abstract}

\section{Introduction}

According to World Health Organization there are four levels of visual function including: a) normal vision, b) moderate visual impairment, c) severe visual impairment and d) blindness. The International Classification of Diseases refers to Moderate visual impairment together with severe visual impairment as "low vision" that together with blindness stands for all visual impairment worldwide (WHO, 2016). 
Blindness is a severe or total change of one or more of the vision basic features that affects the ability to identify color, size, distance, shape, position or movement. It may occur from birth (congenital) or later due to organic or accidental causes. In some cases, blindness may be associated with loss of hearing (deaf-blindness) and/or other disabilities (Sá, 2007, WHO 2016).

According to the literature, $80 \%$ of the human relationships with the world is using sight. It is essential to have all the visual sensory apparatus (eyes, optic nerves, brain optic pathways and the occipital visual cortex) to live fully in our society, emotionally, socially and professionally (Brasil, 2008). The vision loss is partially offset by other senses such as hearing, touch, smell, and taste. Thus, the visually impaired people perceive the world around them through these remained senses (e.g., Braille reading) (Rangel, 2010).

According to the literature, only recently inclusion policies have been created in some countries to allow the visually impaired people to perform a range of everyday activities, such as studying and competing in the labor market. As a result of these policies, we are now able to see more visually impaired people in our society working and living their lives outside their homes as citizens.

Despite this apparent evolution, less development is detected when it comes to teach this public. Concepts that are essential for living in our society such as Mathematics are still difficult of teaching for blind students needing more research, strategies and didactic materials. The development of these materials may offer the same quality level offered to non-visually impaired students (Brawand \& Johnson, 2016).

In this work, we intend to briefly discuss blindness in the perspective of teaching Mathematics. Herein we emphasized the need for developing not only new strategies and materials to teach visually impaired students but also researches regarding new methods to teach them. Finally, we pointed teachers and professors as the future researchers in this area that should occupy this space on human and biological sciences for improving these knowledge areas. 


\section{Methodology}

We performed a search on Google Scholar using the words teaching, blind, visually impaired and Mathematics. This search led to 16,300 results with few published studies related to experiences aimed at teaching Mathematics to visually impaired students in the classroom. Those hits were evaluated in relation to the applicability of teaching Mathematics in the classroom to these students in a inclusive way.

\section{Results}

Mathematics is the science of logical and abstract reasoning that studies amounts measures, spaces, structures, variations and statistics. Because of its complexity, teaching Math to blind or low-vision students demand activities that lead to the exploration of these Mathematical concepts using other senses of these students (eg. touch) in order to provide a full and comprehensive learning (Brawand \& Johnson, 2016).

According to teachers from The Benjamin Constant Institute (IBC), a Brazilian federal institution specialized in teaching visual impairment people, students often arrive into IBC segregated by society and even by family. Some students reported that they felt "pushed aside" in their previous schools, with low self-esteem, not believing in their potential and with an exaggerated aversion to Mathematics discipline (IBC, 2015). On that matter, a question is raised about what is the teacher role as a facilitator to a meaningful and significant learning in a general (concepts for life) and specific perspective (eg. Mathematics).

According to Karling a meaningful learning is a learning for life, applicable and related to the individual experiences. It is a learning linked to the aspirations and the student's reality where the concepts learned improve their life (Karling, 1991).

At the present moment the educational professionals are not well prepared as the universities and colleges do not teach them how to use "inclusive strategies" to teach classes with visually impaired students, whether blind or low vision, especially in Mathematics. In addition, the current textbooks are extremely visual with almost no textbooks appropriately 
adapted for the visually impaired students. These books should use the Braille system, a writing system with raised dots created by Louis Braille, which enables these people to read by touch, also allowing the writing (anagliptography).

Currently, it is clear that the difficulty of teaching and learning Mathematics is not limited only to this public. However the blind student, also including the low vision student that also need adapted materials, have great difficulty to learn Math due to the complexity and abstraction of most topics of this discipline, such as geometry. In Brazil, for example, the visually impaired students have to know 63 signals formed by points from a matrix assembly formed by 6 points, standardized by spelling Braille for the Portuguese language, which form the Braille system (IBC, 2016).

Based in this scenario, it is important to have teachers with in-depth knowledge of Braille for Math, including the regulation Mathematical code CMU, for both reading and writing. This code is oriented to the reading and writing in Braille Mathematics, which contained signals that do not exist in Portuguese in the "handwriting" form. One example is the use of auxiliary brackets, which is a particular feature of Braille. These situations require a teacher trained in writing and reading Braille and in adapting materials for the visually impaired (blind and low vision) students. These educational professionals should know how to use other strategies such as Soroban, an instrument that has standards and methods for using Math calculations (Peixoto et al 2009; Cerqueira et al 2007; Fernandes et al., 2012).

A disturbing situation in Brazil and probably in many countries regarding to the learning process of visually impaired students is the entrance of these students in the 2nd stage of primary education (6th to 9th grade) with many gaps in Mathematics content. This hugely compromises their learning and makes it more difficult to teach them Math, as the topics to be taught depend on the previous concepts that were not learned.

Mathematics is considered one of the most difficult educational subjects to be taught due to the constant need for abstraction. From the perspective of the teaching activity, it requests the development of logical thinking, the encouragement of independent thinking, creativity and problem-solving skills, among others demands to attend. 
Currently the practice of teaching students without special needs is performed to stimulate learning situations in order to develop self-confidence, organization, concentration, attention, deductive logical reasoning, cooperative sense and others activities requested and related to daily life. This should be deeply pursued for the visually impaired students due to the main characteristic of our society that is based in the vision capacity, compromising the possibility of a full life for this public.

According to Reily, students with visual impairment are more likely to have difficulties on learning Mathematics since a very young age if not offered educational resources and teaching strategies suited to their needs. These students will not keep up the Math content neither in the early grades of elementary school nor from the 5th grade and beyond when the requirements start to increase. On that matter, the Math teacher should discover interests, needs and problems of these students, choosing content, techniques and strategies, providing appropriate materials and creating a favorable environment for their study. The teacher, according to Karling, is an important agent to facilitate learning (Reily, 2004; Karling, 1991).

Our world is shown through shapes and colors and the same happens with the teaching materials, as well as, for example, the Mathematics textbook. These didactic books present a high incidence of scenes and visual activities, which are not well adapted for the visually handicapped, especially blind students, losing their meaning even when using audio description (Leuders, 2016).

The predominance of visual resources for teaching Math leads to a fragmented view of reality and decreases the interest and motivation for learning of blind and low vision students. Thus these resources should be constructed and/or situations and everyday experiences that encourage exploration and full development of other senses should be considered. The variety, suitability and quality of these resources are essential to provide and guarantee the access of knowledge, communication and meaningful learning of mathematics.

Some very important criteria should be followed for constructing Mathematics teaching materials for blind students (Figure 1). These criteria should guarantee the efficiency of using 
these educational tools to teach Math. Among them, one of the most important is the fidelity of the representation that should be as accurate as possible to the original model. Furthermore, it should be attractive to the sight and pleasant to the touch. Adequacy is another criterion to be met, considering the relevance to the content and age (Brawand \& Johnson, 2016).

The teaching resources for visually impaired students were all physical resources until recently when the computational technology arrived to contribute to teach this public (Mulloy, 2014; Gasparetto, 2016). These physical resources can be used in all disciplines or areas of study, depending on the techniques or methods employed, aiming to help the student to achieve their learning more effectively (Sá, 2007).

Figure 1: Criteria to be followed for constructing educational materials targeting visually impaired students

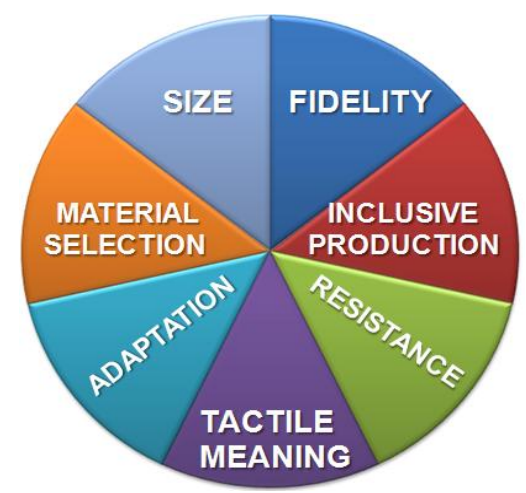

The visually impaired students need adapted materials in their scholar daily life. These materials should be suitable for teaching them by exploring tactile, hearing, smelling, graphic kinesthetic knowledge and Braille perspectives. The adequacy of these materials should ensure the access to all information that other children have so the visually impaired students will be not at disadvantage when compared to their colleagues (Nunes et al, 2010). It is important to notice that such materials and strategies could also benefit students without disabilities as they decrease the complexity level of the topics approached when constructed with the inclusive perspective (Viginheski, 2014).

According to the literature about the use of pedagogical materials for teaching Mathematics to visually impaired students and/or adapted teaching experiences in the 
classroom with this public, researches are still in need. A search on Google Scholar using the words teaching, blind, visually impaired and Mathematics showed 16,300 hits with few published studies related to teaching of visually impaired students. This result reinforced the hypothesis about the lack of studies with practical experience in Mathematics, especially with the use of suitable teaching resources and teaching strategies, for visually impaired students. Articles such as those reported by Zuffi (2011), Cerva Son (2014) and Sá (2014) may help teachers that work with Mathematics contents, especially those topics that require vision with the visually impaired students.

In Brazil, recreational activities such as Origami have been used for teaching Math leading to events such as the Public Scholar Olympics Games of Math (Rego et al., 2015; Cavacami \& Furuya 2009; Genova, 2008; Racan et al., 2015). However, other strategies of simple use and low cost that allow teaching classes with all students learning together, including impaired and non-impaired ones, still have to be developed. On that matter, the Math teacher is one of the most well prepared professional to perform these researches using the "theory and practice" strategy.

According Bortoni (2008), the term "theory and practice" comes from research performed by teachers when they acquire knowledge that influence their practical/professional actions contributing to their teaching performance. The teacher researcher is not seen only as an user but also as someone who propose and produce knowledge about their professional problems to improve their practice. What distinguishes teachers who research from the others is the commitment to reflect their own practice, seeking to strengthen and develop themselves and overcome their own shortcomings, always opened to new ideas and strategies (Bortoni, 2008).

According to Karling (1991), teaching is to discover student interests, needs and problems; choose content, techniques and strategies; providing adequate materials and creating a favorable environment for the student studies. Gil (2002) discussed that teachers have to transform themselves in researchers and among the requirements to do that, they have to present personal qualities to succeed in their research. These qualities are: a) curiosity, b) creativity, c) intellectual integrity, d) self-correcting attitude, e) social sensitivity, f) 
perseverance, g) disciplined imagination, h) patience, f) knowing the subject, and g) confidence in the experience.

For contributing to the Mathematics teaching-learning process of the visually impaired students these new developed instruments should be evaluated with these subjects. These studies should lead to proper tested and safe teaching strategies and materials. This information should be accessible for all and these materials should be offered and/or reported in free and accessible sites in a open access format.

\section{Conclusion}

Despite the progress about studies involving teaching Mathematics, we may concluded that they are not that useful in the classroom when it comes to teach visually impaired students. Thus it is necessary not only to develop more strategies for the education of these people with special needs to allow their improvement but also to increase the production of inclusive materials with the same quality of those offered to non-impaired students.

\section{Acknowledgments}

We thank the Foundation for Research of the Rio de Janeiro State (FAPERJ), National Council for Scientific and Technological Development (CNPq), Teaching Personnel Improvement Coordination (CAPES) and Federal Fluminense University (UFF) for their financial support. We also thank for H.C.C and L.S.A fellowships.

\section{References}

1. Abrão, M. S. 2005. Órgãos do sentido: Visão, audição, tato, olfato e paladar. Especial para a Página 3 Pedagogia \& Comunicação. São Paulo.

2. Baumel, R. C. R. C et al. 2005. Materiais e Recursos de Ensino para Deficientes Visuais. In: Ribeiro, M. L; Baumel, R. C. Educação Especial: Do querer ao Fazer. São Paulo: Avercamp , p. $95-107$. 
3. Brawand, A., \& Johnson, N. (2016). Effective Methods for Delivering Mathematics Instruction to Students with Visual Impairments.

4. Bortoni-Ricardo, S. M. 2015. O professor pesquisador: Introdução à pesquisa qualitativa. Parábola Editorial, São Paulo.

5. Brasil MEC. 2006. Secretaria de Educação Especial. Código Matemático Unificado para a Língua Portuguesa- CMU, Brasília.

6. Brasil, MEC. 1998. O recurso às tecnologias da Informação. - Brasília: SEF. p. 75.

7. Brasil, Ministério Da Saúde e MEC. 2008. Projeto OLHAR BRASIL. Available in: http://biblioteca.ibge.gov.br/visualizacao/periodicos/94/cd_2010_religiao_deficiencia.pdf. Brasília. Accessed in: 08/22/2016.

8. Brasil, Ministério da Saúde. 2008. Projeto Olhar Brasil: triagem de acuidade visual: manual de orientação / Ministério da Saúde, Ministério da Educação. - Brasília: Ministério da Saúde. 24 p.: il. - (Série A. Normas e Manuais Técnicos).

9. Brasil, Secretaria de Educação Fundamental. 1998. Parâmetros curriculares nacionais: Adaptações curriculares: Estratégias para a educação de alunos com necessidades educacionais especiais. Brasília: MEC/SEF. 62p.

10. Brasil. Secretaria de Educação Fundamental. 1997. Parâmetros curriculares nacionais: Matemática / Secretaria de Educação Fundamental. Brasília: MEC/SEF. Available in: http://portal.mec.gov.br/seb/arquivos/pdf/livro03.pdf. Accessed in: 04/05/2015

11. Cavacami, E., Furuya, Y. K. S. 2009. Explorando Geometria com Origami. Departamento de Matemática - Universidade Federal de São Carlos. Available in: http://www.dm.ufscar.br/ yolanda/origami/origami.pdf. Accessed in 03/04/2015.

12. Cerqueira, J. B. et al. 2007. Técnicas de Cálculo e Didática do Soroban. $2^{a}$ edição revista e atualizada de acordo com a Portaria IBC/GAB n 64.

13. Chagas, P. W. V. 2011. O estímulo enquanto fator que contribui para a aprendizagem do deficiente visual. Udesc em Ação, V. 5, n. 1, p. 1 - 19.

14. Costa, E. M. 2007. Matemática e origami: trabalhando frações. Ciência Moderna.

15. Fernandes, C. T. et al. 2012. Manual de Técnicas Operatórias para Pessoas com Deficiência Visual, Brasília.

16. Gaspareto, M. E. R. F. 2012. Tecnologias assistivas e práticas pedagógicas inclusivas: deficiência visual. Oficina Universitária. São Paulo. Cultura Acadêmica. Páginas 159 -184. 
Available in: https://www.marilia.unesp.br/Home/Publicacoes/as-tecnologias-naspraticas_e-book.pdf. Accessed in: 04/24/2016.

17. Genova, C. 2008. Origami, contos e encantos. São Paulo: Escrituras Editora.

18. Gil, A. C. 2002. Como elaborar Projetos de Pesquisa. Atlas. São Paulo.

19. IBC, O Sistema Braille no Brasil. Available in: http://www.ibc.gov.br/?itemid=10235. Accessed in: 08/22/2016.

20. IBC, Recursos Didáticos na Educação Especial. Available in: http://www.ibc.gov.br/?itemid=102\#more. Accessed in: 08/23/2015.

21. Karling, A. A. 1991. A Didática Necessária. São Paulo: Ibrasa.

22. Leuders, J. 2016. Tactile and acoustic teaching material in inclusive mathematics classrooms. British Journal of Visual Impairment, 34(1), 42-53.

23. Mulloy, A. M., Gevarter, C., Hopkins, M., Sutherland, K. S., \& Ramdoss, S. T. 2014. Assistive technology for students with visual impairments and blindness. In Assistive technologies for people with diverse abilities (pp. 113-156). Springer New York.

24. Nunes, M. F. R. et al. 2004. Experiências bem-sucedidas em Escolas Públicas.

25. Peixoto, J. L. B. et al. 2009. Uma ferramenta para compreensão das quatro operações. Itabuna, BA. Via Litterarum.

26. Rancan, G. et al. Geometria com origami: incentivando futuros professores. Available in: http://www.portalanpedsul.com.br/admin/uploads/2012/Ensino_de_Matematica_e_ciencia s/Trabalho/12_36_51_316-7152-1-PB.pdf. PUCRS. Accessed in: 05/18/2015

27. Rangel, M. L. et al. 2010. Deficiência visual e plasticidade no cérebro humano. Psicol. teor. prat.[online].vol.12, n.1 [citado 2016-05-28], pp. 197-207. Available in: http://pepsic.bvsalud.org/scielo.php?script=sci_arttext\&pid=S151636872010000100016\&lng=pt\&nrm=iso. ISSN 1516-3687. Accessed in: 10/09/2015.

28. Rêgo, R. G.; Rêgo, R. M; Gaudêncio, S. 2004. A geometria do Origami: atividades de ensino através de dobraduras. João Pessoa: Editora Universitária/UFPB. Available in: http://www.ucs.br/etc/conferencias/index.php/anpedsul/ganpedsul/paper/viewFile/316/537 . Accessed in 04/24/2015.

29. Reily, L. 2004. Escola Inclusiva:Linguagem e mediação. Campinas: Papirus (Série Educação Especial). 
30. Sá, E. D. et al. 2007. Atendimento Educacional Especializado: Deficiência Visual. São Paulo: MEC/SEESP.

31. Sá, I. P. 2010. A magia da Matemática. Rio de Janeiro, Ciência Moderna.

32. Sá, P. F. 2014. Matemática por atividades. Experiências didáticas bem sucedidas. Vozes. Petrópolis, RJ.

33. Viginheski, L. V. M., Frasson, A., da Silva, S. D. C. R., \& Shimazaki, E. M. 2014. O sistema Braille e o ensino da Matemática para pessoas cegas. Ciência \& Educação, 20(4), 903-916.

34. WHO. Accessed at http://www.who.int/mediacentre/factsheets/fs282/en/ in 2016.

35. Zuffi, E. M. et al. 2011. Pesquisas sobre a inclusão de alunos com necessidades especiais no Brasil e a aprendizagem em Matemática. XIII Conferência Interamericana de Educação Matemática (CIAEM), Available in: http://www.gente.eti.br/lematec/CDS/XIIICIAEM/artigos/1336.pdf. Accessed in 03/03/2016. 